\title{
RAINWATER HARVESTING AS AN ALTERNATIVE SOURCE OF DOMESTIC WATER IN LAMPUNG PROVINCE - INDONESIA
}

\author{
Gatot Eko Susilo', Tri Budi Prayogo² \\ Received: May, $21^{\text {st }} 2018$ \\ Accepted: October, $17^{\text {th }} 2018$
}

\begin{abstract}
Urban areas in Indonesia will experience water crisis in the future due to the rapid population growth. Local water companies will face big problems to meet the water needs of these cities in the future, due to limited water resources and environmental degradation. Efforts to find new alternative water sources are important to undertake to ensure the availability of clean and fresh water in the future. This paper aims to investigate the effectiveness of rainwater harvesting facility and the potential benefits of rainwater harvesting applications in urban areas in Indonesia. The cities that are the object of research are Bandar Lampung, Pringsewu, and Metro City. These three cities are the fastest growing cities in Lampung Province. Simulation to find supporting capacity of RWH is applied for house type 45 , which has an effective rooftop area of $30 \mathrm{~m} 2$. The maximum capacity of the tanks being tested is $1 \mathrm{~m}^{3}$ and $2 \mathrm{~m}^{3}$, and the number of occupants is 5 to 7 people. Research shows that RWH has great potential to meet domestic water demand in major cities in Indonesia. From some analysis and simulation of this research, it is known that the supporting capacity of RWH for domestic water supply in the cities studied is $40 \%$ to $50 \%$ on average. Research also shows that reservoir size $2 \mathrm{~m} 3$ is the most recommended dimension in RWH implementation in Lampung Province cities.
\end{abstract}

Keywords: Rainwater harvesting, Effectiveness, Domestic water

\section{INTRODUCTION}

Indonesia is a tropical country, therefore Indonesia has only two seasons, rainy and dry seasons. As a tropical country, rainfall in Indonesia is quite a lot, about $2500 \mathrm{~mm}$ to $3500 \mathrm{~mm} /$ year (Susilo, 2015). The wet season generally occurs on the October to March. The islands in Indonesia that have high rainfall are Sumatera Island, Java Island, Borneo Island and Papua Island. Although in general the rainfall in Indonesia is high but there are some regions in Indonesia that have low rain intensity such as Sulawesi and Nusa Tenggara. In Indonesia, rain water can be used for various purposes such as for irrigation, plantation, water domestic, and others. For irrigation and plantations, rainwater is the source of water for rivers or reservoirs. On the other hand, rainwater supplies water for shallow wells that are widely used to meet water domestic for Indonesian people. Unfortunately, with high rainfall in the area, Indonesians have not used rain water more wisely. In general, some of the rainfall becomes the drainage discharge and the cause of the flood.

\footnotetext{
${ }^{1}$ Civil Engineering Department., University of Lampung,

${ }^{2}$ Water Resources Engineering Brawijaya University

Correspondence: gatot89@yahoo.ca
} 
In other countries, rainwater harvesting is not new. Countries in South Asia such as India, Pakistan, Sri Lanka, and Bangladesh have been doing it since long ago and still do so until now. In Africa, rainwater harvesting plays an important role in the management of irrigation and domestic water supply (Bruins et al., 1986; Handia et al., 2003; Hatibu et al., 2006). In Taiwan, rainwater harvesting has been used to meet the needs of non-potable water (Chiu et al., 2009), and in China research on rainwater harvesting applications for irrigation supplementation has also been carried out (He et al., 2007). In developed countries such as Japan, Western Europe and North America, rainwater harvesting is already a very important water component to be considered economically and socially.

\section{Problem Identification}

Lampung is a one of provinces in Indonesia where located on the southern area of Sumatera Island. This province has area of $35,376.50 \mathrm{~km}^{2}$ and consists of 3 cities and 15 regencies. The capital of the province is Bandar Lampung with surrounding cities Pringsewu and Metro. Geographically, Lampung lies between $105^{\circ} 45^{\prime}-103^{\circ} 48^{\prime} \mathrm{E}$ and $3^{\circ} 45^{\prime}-$ $6^{\circ} 45^{\prime}$ S. The province is adjacent to the Indian Ocean, Java Sea, South Sumatra Province, and Sunda Strait in the east, west, north, and south, respectively. The western part of Lampung is a hilly coastal area that is part of the Bukit Barisan mountains. The southern part is largely a white sandy beach. The middle and north are lowland areas and the eastern part is coastal area as part of the Malacca Strait and the Java Sea. Average temperature in Lampung is $25^{\circ} \mathrm{C}$. The highest and lowest temperature is $33^{\circ} \mathrm{C}$ and $21^{\circ} \mathrm{C}$, respectively. The coldest month is April and the hottest month is January. Average rainfall in Lampung is $160 \mathrm{~mm}$ per month with the duration of dry season and rainy season of 6 months, respectively. According to the census of 2017, the population of Lampung Province is $12,904,906$ people and consists of various ethnics. The biggest ethnic is Java ethnic with $65.80 \%$ of all Lampung population. Number of native people was recorded about $12.80 \%$ of whole Lampung population.

Bandar Lampung is the largest city in Lampung and is the third largest city on the island of Sumatera after Medan and Palembang. In 2015, population of Bandar Lampung was $1,166,761$ people. This number is followed by ones of two other biggest cities, Pringsewu and Metro. Data showed that the population of Pringsewu and Metro was 386,891 and 161,183 people, respectively. Bandar Lampung, Pringsewu and Metro are urban areas that will experience water crisis in the future due to the rapid population growth. Local water companies will face big problems to meet the water needs of these cities in the future, due to limited water resources and environmental degradation. Therefore, efforts to find new alternative water sources are important to undertake in order to ensure the availability of clean and fresh water in the future.

Rainfall can be used as one of alternatives of fresh water source. Rainfall in Lampung generally ranges from $2,000 \mathrm{~mm}$ to $3,000 \mathrm{~mm}$ per year with good quality for domestic nonconsumption and sanitation water. Rainwater utilization is a potency that must be explored to support domestic water needs in urban areas of the Province. Several places in rural Lampung have used rain as an alternative source of fresh water, although it is implemented in a simple and sporadic way. In urban areas, rainwater harvesting is still something new. In 2017, the Government of Lampung Province has just socialized the use of rain water for the first time. Until now the exact formulation of the most effective shape and dimensions of rainwater harvesting installation in cities in Lampung Province has not been established yet. Therefore, this paper aims to investigate the effectiveness of rainwater harvesting facility and the potential benefits of rainwater harvesting applications in these cities. The cities that are the object of research are Bandar Lampung, Pringsewu, and Metro City. 
These three cities are the fastest growing cities in Lampung Province. The main income of these cities is the trade in goods and services. Because of its relatively close proximity to Jakarta, many growing businesses are branch businesses from Jakarta. Its populations, mostly migrants and hard workers, are another reason for the rapid growth of businesses in the three cities.

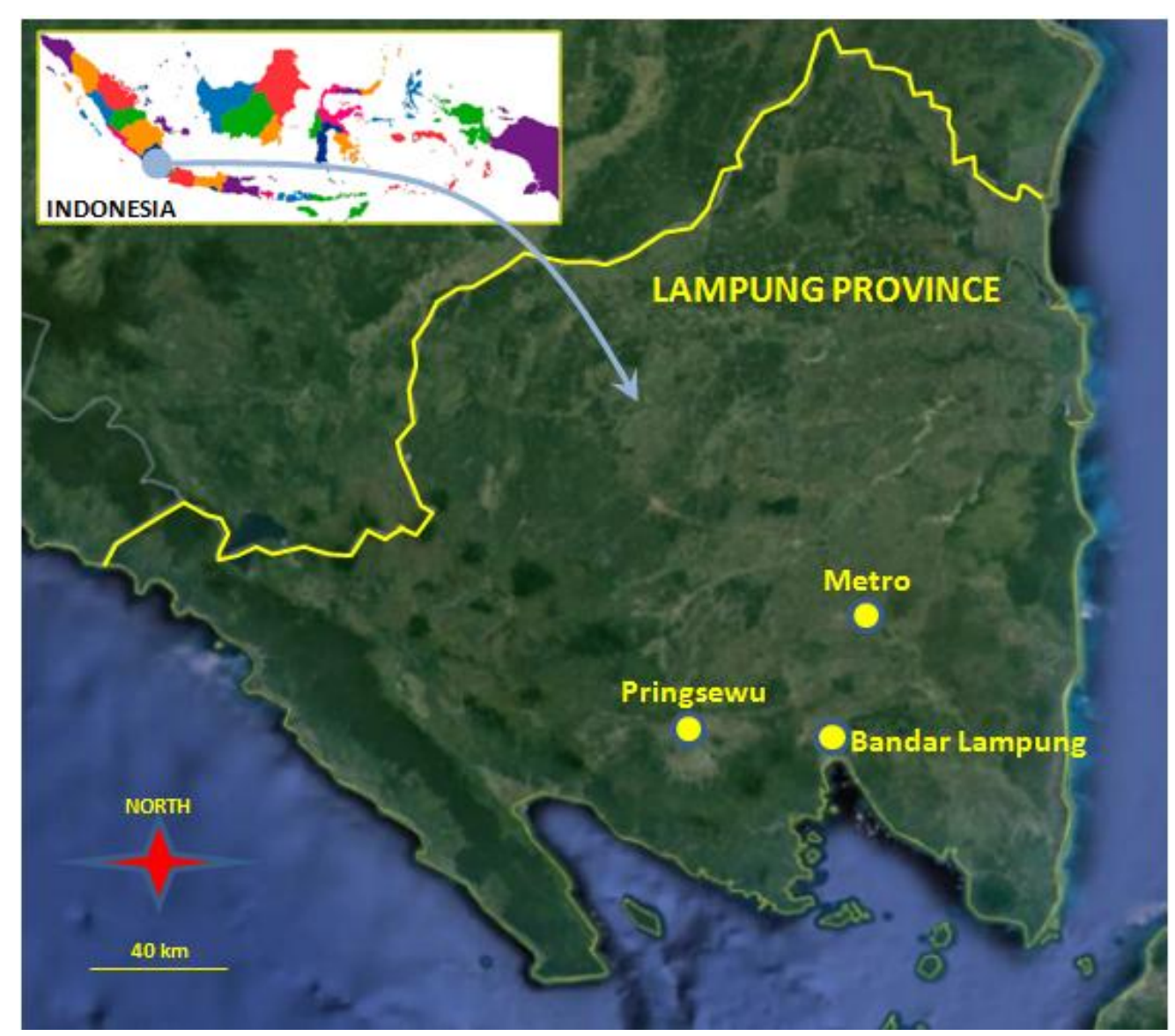

(adaptation from Google Map with modification)

Figure 1. Bandar Lampung and surrounding cities

\section{Theori of Rainwater Hawesting (RWH)}

Basically rainwater harvesting (RWH) is the activity of collecting rainwater and storing it in a reservoir with the aim of utilizing the water for various purposes such as maintaining the sustainability of groundwater or as an alternative source of fresh water. The RWH facility that aims to maintain groundwater preservation is usually infiltration well, while RWH's main facility which aims to fulfill domestic water needs is a water reservoir and its equipment. Water reservoirs can be built either above or below the ground. In this research, RWH is intended for the fulfillment of domestic water needs. This type of RWH consists of several basic components such as: rooftop area, gutter, gutter filter, inlet pipe, water reservoir, outlet pipe, outlet filter, and distribution pump. RWH can be built on a large scale for example for office or school areas. The determination of the reservoir dimension at large-scale RWH depends on the amount of annual rainfall. 
However, for RWH on a household scale the size of the reservoir is highly dependent on land availability.

During this time the water from RWH can not be used for drinking water. Although there have been several studies investigating the possibility of rainwater as drinking water but the publication is still very rare. A study in Riau Province noted that rainwater quality was slightly below drinking water quality standards (Anuar et al., 2015). This means that rainwater is safe for sanitation purposes.

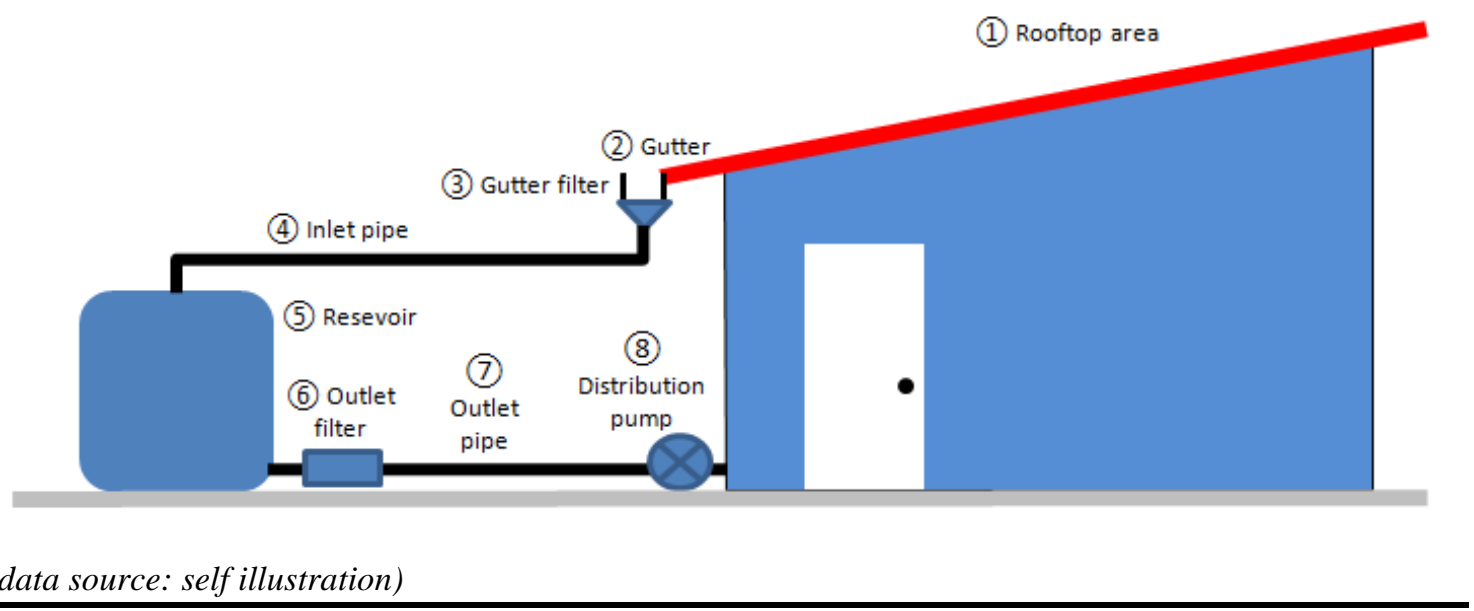

Figure 2. RWH system

\section{METHOD}

In order to determine the optimum dimension of rainwater tank in the RWH facility, it is necessary to calculate inflow and outflow rate coming to and going from the reservoir. Inflow comes from the rainfall caught by rooftop of the house and outflow is the water used by the house inhabitants. The water balance in the tank is calculated using water balance model (Khastagir and Jayasuriya, 2010; Susilo et al., 2011) as follows:

$$
S_{t}=S_{t-1}+\text { Inflow }- \text { Outflow }
$$

where, $S_{t}$ is water volume in the tank on day $t\left(\mathrm{~m}^{3}\right)$ and $S_{t-1}$ is water volume in the tank at day $t-1\left(\mathrm{~m}^{3}\right)$. The volume of water in the tank ranges between 0 to maximum capacity of the tank $\left(S_{\max }\right)$.

Inflow is the function of roof catchment area $(A)$, runoff coefficient of the roof $(C)$, and rainfall $(R)$. C value is taken between 0.8 and 1.0 (Fewkes, 1999). Inflow is calculated as follows:

$$
\text { Inflow }=\text { R.A.C } / 1000
$$

On the other hand, outflow is the function of daily personal water demand (D), and number of people in the house (n) and calculated as follows:

$$
\text { Outflow }=n \cdot D
$$


Water balance simulation in this research involves daily rainfall data of years 2013, 2014, and 2015. The data are obtained from Mesuji Sekampung River Organization (BBWS Mesuji Sekampung) of Public Work and Human Settlement Ministry. Rainfall data used in simulation for Bandar Lampung, Pringsewu, and Metro is the data from Kemiling (PH005, Fajar Esuk (R006), and Metro Barat (R054) rain gauge stations, respectively. The data are presented below:

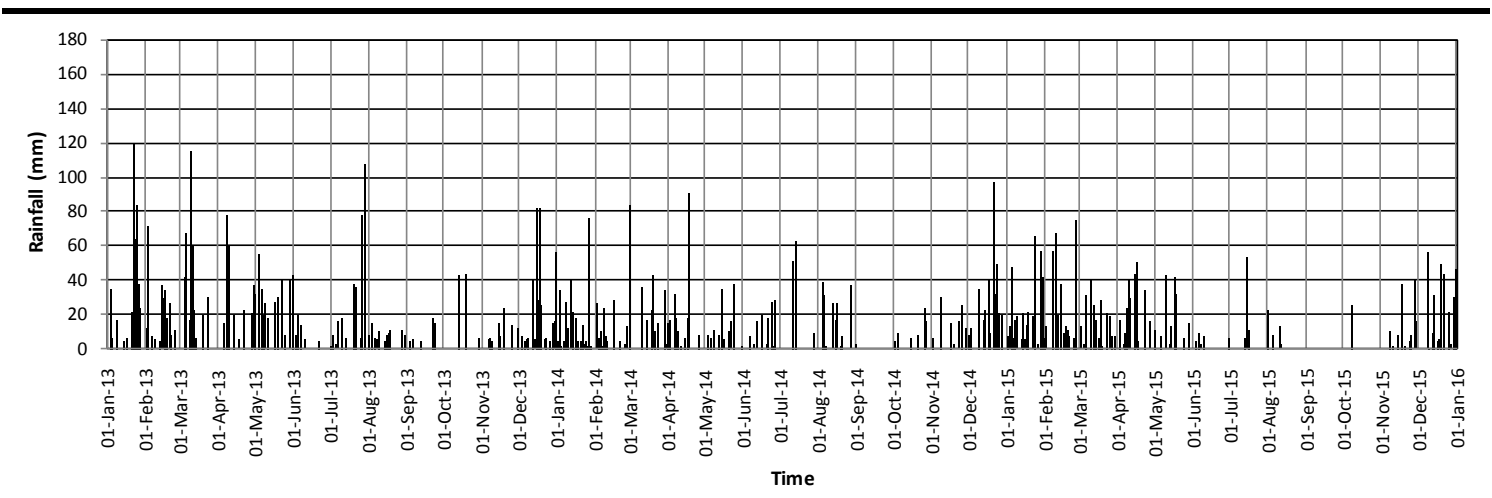

(a)

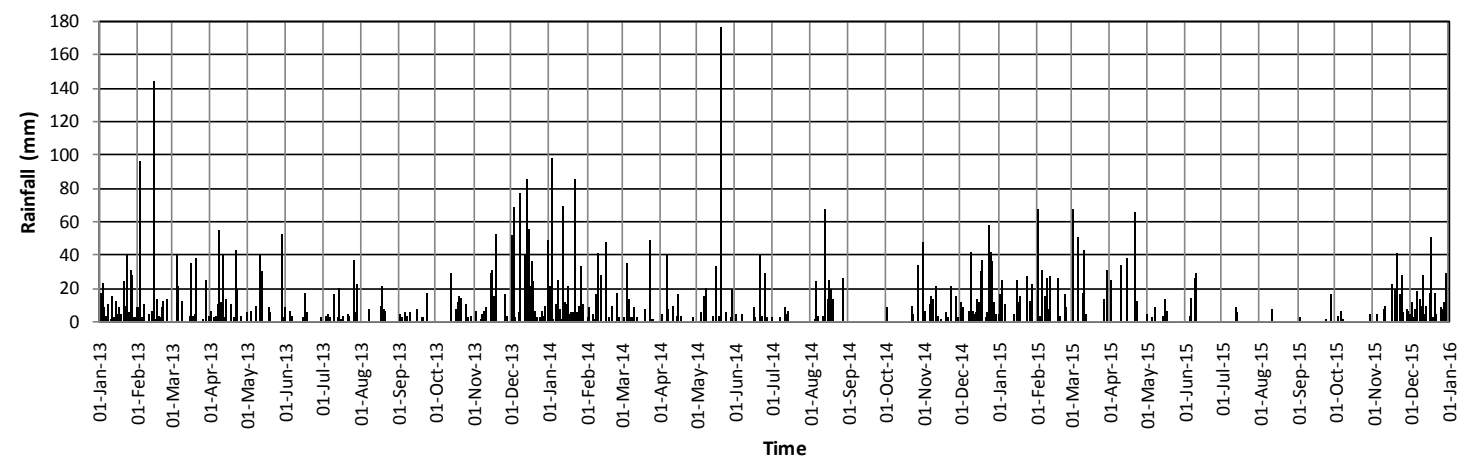

(b)

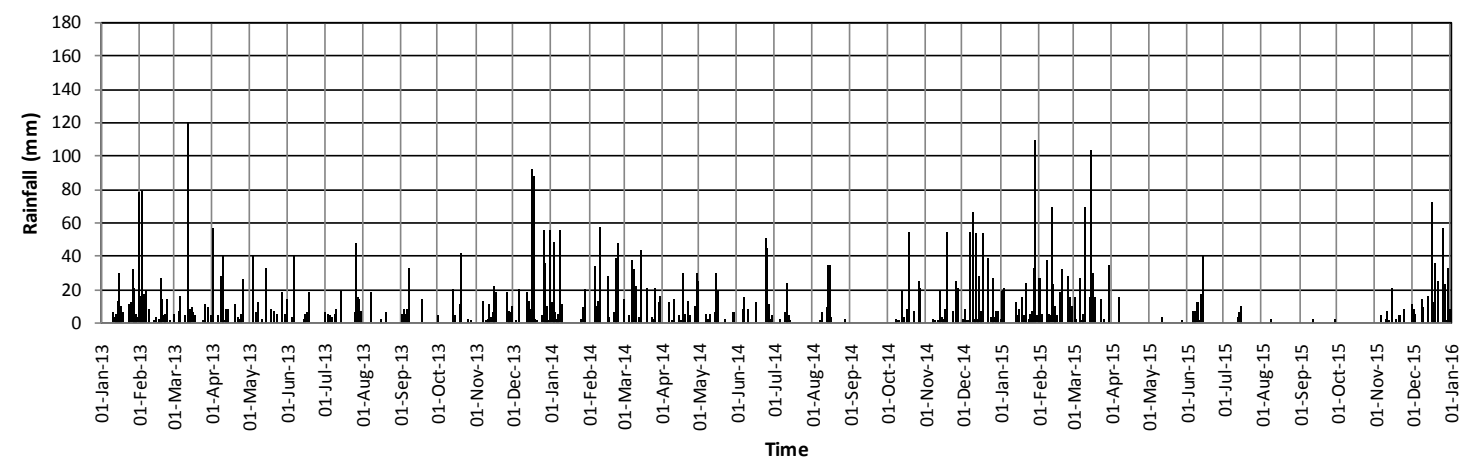

(c)

(data source: Mesuji Sekampung River Organization)

Figure 3. Daily rainfall data of study areas: Kemilling (a), Fajar Esuk (b), and Metro Barat (c)

Numerically, data above is presented as follows: 
Table 1. Daily rainfall data of study areas

\begin{tabular}{ccccccc}
\hline \multirow{2}{*}{ Year } & \multicolumn{2}{c}{$\begin{array}{c}\text { Kemiling Stations } \\
\text { for Bandar Lampung City }\end{array}$} & \multicolumn{2}{c}{$\begin{array}{c}\text { Fajar Esuk Stations } \\
\text { for Pringsewu City }\end{array}$} & \multicolumn{2}{c}{$\begin{array}{c}\text { Metro Barat Stations } \\
\text { for Metro City }\end{array}$} \\
\cline { 2 - 7 } & Rainfall (mm) & $\begin{array}{c}\text { \# of Rainy } \\
\text { Day }\end{array}$ & Rainfall (mm) & $\begin{array}{c}\text { \# of Rainy } \\
\text { Day }\end{array}$ & $\begin{array}{c}\text { Rainfall (mm) } \\
\text { \# of Rainy } \\
\text { Day }\end{array}$ \\
\hline 2013 & 2900 & 118 & 2391 & 165 & 2074 & 145 \\
2014 & 2058 & 112 & 2049 & 139 & 1975 & 131 \\
2015 & 2059 & 106 & 1419 & 91 & 1539 & 95 \\
\hline
\end{tabular}

Source: Calculation, 2018

Supporting capacity of RWH is the carrying capacity of RWH to replace the use of groundwater for domestic water within 1 year. Supporting capacity of RWH is the ratio of the number of days whose domestic water can be met by RWH with the number of days in a year. Simulation to find supporting capacity of RWH is applied for house type 45, which has an effective rooftop area of $30 \mathrm{~m}^{2}$. The maximum capacity of the tanks being tested is $1 \mathrm{~m}^{3}$ and $2 \mathrm{~m}^{3}$, and the number of occupants is 5 to 7 people. Type 45 of house is the most widely used type in the community. Similarly with other variables, the house in Lampung usually consists of 4 to 7 residents. The maximum water reservoir capacity that may be used for household scale is $1 \mathrm{~m}^{3}$ or $2 \mathrm{~m}^{3}$ with domestic water needs 50 liters per day (Wulan, 2005; Washilatur, 2008).

\section{RESULTS AND DISCUSSIONS}

To find RWH supporting capacity with various parameter values, 48 simulations have been performed for each city. Results of the simulation for each city is presented as follows:

Table 2. RWH Supporting capacity of Bandar Lampung City

\begin{tabular}{cccccc}
\hline \multirow{2}{*}{$\begin{array}{c}\text { Volume of } \\
\text { reservoir }\end{array}$} & $\mathrm{n}$ & \multicolumn{4}{c}{ RWH Supporting capacity } \\
\cline { 3 - 6 } $1 \mathrm{~m}^{3}$ & 4 & 2013 & 2014 & 2015 & Average \\
& 5 & $42,9 \%$ & $55,1 \%$ & $50,4 \%$ & $52,8 \%$ \\
& 6 & $38,1 \%$ & $35,5 \%$ & $41,6 \%$ & $42,4 \%$ \\
& 7 & $34,0 \%$ & $29,6 \%$ & $34,2 \%$ & $35,8 \%$ \\
\hline $2 \mathrm{~m}^{3}$ & 4 & $62,5 \%$ & $62,5 \%$ & $55,9 \%$ & $60,9 \%$ \\
& 5 & $53,7 \%$ & $48,8 \%$ & $48,8 \%$ & $50,4 \%$ \\
& 6 & $46,3 \%$ & $40,5 \%$ & $41,6 \%$ & $42,8 \%$ \\
& 7 & $41,1 \%$ & $34,2 \%$ & $34,2 \%$ & $36,5 \%$ \\
\hline
\end{tabular}

Source: Calculation, 2018

Table 3. RWH Supporting capacity of Pringsewu City

\begin{tabular}{cccccc}
\hline \multirow{2}{*}{$\begin{array}{c}\text { Volume of } \\
\text { reservoir }\end{array}$} & $\mathrm{n}$ & \multicolumn{4}{c}{ RWH Supporting capacity } \\
\cline { 3 - 6 } $1 \mathrm{~m}^{3}$ & 4 & 2013 & 2014 & 2015 & Average \\
\hline & 5 & $51,5 \%$ & $46,0 \%$ & $39,7 \%$ & $45,8 \%$ \\
& 6 & $30,0 \%$ & $38,6 \%$ & $30,7 \%$ & $36,4 \%$ \\
& 7 & $28,2 \%$ & $32,6 \%$ & $26,0 \%$ & $30,5 \%$ \\
& 4 & $59,5 \%$ & $52,9 \%$ & $46,0 \%$ & $52,8 \%$ \\
& 5 & $47,9 \%$ & $44,1 \%$ & $36,2 \%$ & $42,7 \%$ \\
& 6 & $39,5 \%$ & $37,0 \%$ & $28,5 \%$ & $35,0 \%$ \\
& 7 & $34,0 \%$ & $32,1 \%$ & $23,8 \%$ & $30,0 \%$ \\
\hline
\end{tabular}

Source: Calculation, 2018 
With a tank or reservoir of $1 \mathrm{~m}^{3}$, the average of RWH supporting capacity for Bandar Lampung city ranges from $30 \%$ to $52 \%$. If the tank size is changed to $2 \mathrm{~m}^{3}$, then the RWH supporting capacity will change to about $36 \%$ to $60 \%$.

For Pringsewu City, the average supporting capacity of RWH for tank capacity of 1 $\mathrm{m}^{3}$ and $2 \mathrm{~m}^{3}$ is about $25 \%$ to $45 \%$ and $30 \%$ to $52 \%$, repectively. The complete supporting capacity of RWH for Pringsewu City can be seen in table 3 .

For Metro City, the average supporting capacity of RWH for reservoir capacity of 1 $\mathrm{m}^{3}$ and $2 \mathrm{~m}^{3}$ is about $24 \%$ to $41 \%$ and $27 \%$ to $48 \%$, repectively. The supporting capacity of RWH for Metro City is given as follows:

Table 4. RWH Supporting capacity of Metro City

\begin{tabular}{cccccc}
\hline \multirow{2}{*}{$\begin{array}{c}\text { Volume of } \\
\text { reservoir }\end{array}$} & $\mathrm{n}$ & \multicolumn{4}{c}{ RWH Supporting capacity } \\
\cline { 3 - 6 } $1 \mathrm{~m}^{3}$ & 4 & 2013 & 2014 & 2015 & Average \\
& 5 & $34,9 \%$ & $47,4 \%$ & $32,6 \%$ & $41,6 \%$ \\
& 6 & $29,0 \%$ & $37,0 \%$ & $26,3 \%$ & $32,7 \%$ \\
& 7 & $25,5 \%$ & $32,6 \%$ & $23,3 \%$ & $28,3 \%$ \\
\hline $2 \mathrm{~m}^{3}$ & 4 & $52,1 \%$ & $58,2 \%$ & $19,2 \%$ & $24,3 \%$ \\
\hline & 5 & $39,7 \%$ & $44,9 \%$ & $30,1 \%$ & $48,4 \%$ \\
& 6 & $32,9 \%$ & $37,5 \%$ & $26,6 \%$ & $32,3 \%$ \\
& 7 & $27,7 \%$ & $32,3 \%$ & $21,9 \%$ & $27,3 \%$ \\
\hline
\end{tabular}

Source: Calculation, 2018

The results above show that the most important component in an RWH application in an area is the amount of rainfall. Rainfall is a parameter that can not be set because it is a natural event that is random. Although the rainy season can be predicted correctly but the date of occurrence and the amount of rainfall is beyond the human ability to predict. If the amount of rainfall becomes large, supporting capacity of RWH value tends to be big. Conversely, if the amount of rainfall becomes less, supporting capacity of RWH value tends to be small. Rainfall determines the maximum capacity of supporting capacity of RWH. Table 2, Table 3, and Table 4 show the year 2015, for each rain gauge station, has the lowest rainfall when compared to other years. This resulted in a small RWH supporting capacity in that year for all cities.

Supporting capacity of RWH is also strongly influenced by climatic factors such as El Nino events. Some studies suggest that areas in western Indonesia are very sensitive to El Nino events (Hamada et al., 2002). El Nino resulted in a decrease in sea surface temperatures around the Western Pacific or the Pacific Ocean around Indonesia. This circumstance encourages the reduction of rain cloud formation so that the rainfall in Indonesia is reduced. Research conducted in 1997 by the Indonesian Meteorological, Climatology, and Geophysical Agency stated that El Nino causes 55\% decrease of rainfall from normal rainfall in Indonesia (Kadarsah, 2007).

The effectiveness of supporting capacity of RWH is also determined by the size of the reservoir tank. If the reservoir tank is too small compared to the amount of rainfall it will result in lower supporting capacity of RWH. The volume of wasted rain water will increase and the function of RWH becomes ineffective. Contrarily, if the reservoir tank is too large compared to the amount of rainfall, the optimum supporting capacity of RWH will never be achieved and the investment cost of RWH development becomes greater. The simulation shows that a reservoir of $2 \mathrm{~m}^{3}$ produces a larger RWH supporting capacity when compared to a reservoir of $2 \mathrm{~m}^{3}$. The size of the reservoir that can generate the 
maximum RWH support capacity can be found by trial and error. However, the maximum reservoir size for house type 45 is $2 \mathrm{~m}^{3}$. This is because larger reservoir sizes will require considerable space and require substantial investment costs. The placement and size of the reservoir on the RWH system installed at home should be adjusted to the architectural form of the house. Based on the results of this study, reservoirs of $2 \mathrm{~m}^{3}$ can be recommended as standard RWH tank dimensions for Bandar Lampung, Pringsewu and Metro cities. The Water tank of $2 \mathrm{~m}^{3}$ capacity is widely available on the market. The dimension of the tank is $163 \mathrm{~cm}$ (height) and $136 \mathrm{~cm}$ (diameter). This water tank is made of fiber glass material that is durable and available with various brands.

The adoption of RWH, on the other hand, not only makes the use of groundwater less for domestic purposes but also saves electricity to operate water pumps that take water from deep wells. On the scale of households in big cities, the cost of electricity to pump groundwater for domestic water can be quite large. When the ground water well is deep enough then the pump efficiency decreases and the pumping time becomes longer. Automatically the electricity cost will become bigger. If a household applies RWH then it is not necessary to pump water from deep wells. Water is available at ground level and can be distributed by gravity or with a pump that is much smaller in size.

\section{CONCLUSSIONS}

The benefits of RWH implementation for household scale in cities in Lampung Province have been analyzed. Research shows that RWH has great potential to meet domestic water demand in major cities in Indonesia. From some analysis and simulation of this research, it is known that the supporting capacity of RWH for domestic water supply in the cities studied is $40 \%$ to $50 \%$ on average. This means that RWH can supply domestic water for 130 days to 190 days within a year in a household. Research shows that reservoir size $2 \mathrm{~m}^{3}$ is the most recommended dimension in RWH implementation in Lampung Province cities. The reason is because the dimensions match the area of house type 45 and widely available in the market.

The application of RWH on a household scale is not only useful for domestic water supply, preserving groundwater, and reducing flood risk but also providing an economic benefit of reducing the cost of electricity normally used for the operating costs of deep groundwater pumps. In the household scale RWH is quite easy to apply and does not require expensive investment cost. To accelerate the spread of RWH implementation in the household scale, the provincial government of Lampung should provide subsidy for reservoir tank procurement.

\section{ACKNOWLEDGEMENT}

The author would like to express his deep gratitude to Mr. Ankavisi Nalaralagi and Mrs. Eka Desmawati from Mesuji Sekampung River Organization (BBWS Mesuji Sekampung) for their support in completing this paper.

\section{REFERENCES}

Anuar, K., Ahmad, A., \& Sukendi. (2015). Analysis of Rainwater Quality as a Source of Drinking Water to Public Health (Case Study in Kecamatan Bangko Bagan Siapi-api). Dinamika Lingkungan Indonesia (in Bahasa Indonesia), 2015:32-39.

Bruins, H.J., Evenari, M., \& Nessler, U. (1986). Rainwater-harvesting agriculture for food production in arid zones: the challenge of the African famine. Applied Geography, 6:13-32. 
Chiu, Y.R., Liauw, C. H., \& Chen, L.C. (2009). Optimizing rainwater harvesting systems as an innovative approach to saving energy in hilly communities. Renewable Energy, 34:492-498.

Fewkes, A. (1999). The use of rainwater for WC flushing: the field testing of a collection system. Building and Environment, 34(6):765-772.

Hamada, J., Yamanaka, M. D., Matsumoto, J., Fukao, S., Winarso, P. A., \& Sribimawati. T. (2002). Spatial and temporal variations of the rainy season over Indonesia and their link to ENSO. Journal of the Meteorological Society of Japan, 80:285- 310.

Handia, L., Tembo, J.M., \& Mwiindwa, C. (2003). Potential of rainwater harvesting in urban Zambia. Physics and Chemistry of the Earth, 28:893-896.

Hatibu, N., Mutabazi, K., Senkondo, E.M., \& Msangi, A.S.K. (2006). Economics of rainwater harvesting for crop enterprises in semi-arid areas of East Africa. Agricultural Water Management, 80:74-86.

He, X.F., Cao, H., \& Li, F.N. (2007). Econometric analysis of the determinants of adoption of rainwater harvesting and supplementary irrigation technology (RHSIT) in the semiarid Loess Plateau of China. Agricultural Water Management, 89.243-250.

Kadarsah. (2007, July 1). Pengukuran data meteorologi di Indonesia (Meteorological data measurement in Indonesia). Retreived from Available at: http://kadarsah.wordpress.com/2007/07/01/pengukurandata-meteorologi-di-indonesia/.

Khastagir, A. \& Jayasuriya, N. (2010). Optimal sizing of rain water tanks for domestic water conservation. Journal of Hydrology, 381(3-4):181-188.

Susilo, G.E., Yamamoto, K., and Imai, T. (2011). The Identification of Rainwater Harvesting Potency in Supporting Freshwater Availability under the Effect of El Nino. Proceeding IWA - ASPIRE International Conference. International Water Association: Paper 17-4-1.

Susilo, G.E. (2015). Experience in Rainwater Harvesting Application at Household Scale in Bandar Lampung, Indonesia. Proceeding of the 1st Young Scientist International Conference of Water Resources Development and Environmental Protection. Water Resources Engineering Dept., Brawijaya University of Malang: B -1 .

Washilatur, R. (2008). Domestic Water Consumption Pattern in Northern Sukoharjo. [BSc Research Paper in Bahasa Indonesia]. Physical Geography Departement. Universitas Muhammadiyah Surakarta. Solo Indonesia.

Wulan, A.I.S. (2005). Evaluation of water quality for domestic water use in Pesarean Village, Adiwerna - Tegal. [BSc Research Paper in Bahasa Indonesia]. Geography Departement. Universitas Negeri Semarang, Indonesia. 